\title{
The Effect of Media Literation on Hoax News Acceptance Among Students
}

\author{
Nahdiana $^{1}$, Andi Suci Adysa ${ }^{2}$ \\ \{nahdiana.dty@uim-makassar.ac.id ${ }_{2}$ a.suciadysa.fisip@uim-makassar.ac.id ${ }^{2}$ \}
}

Department of Communication Universitas Islam Makassar, Jl. Perintis Kemerdekaan, Makassar, Indonesia ${ }^{1,2}$

\begin{abstract}
News or information is very fast circulating through social media. Those who often use social media on a daily basis will get a lot of information from social media. This allows them to be exposed more often to news with sources whose truth is unclear. For those who are not media literate, such a thing is considered right. This requires media literacy in order to reduce hoax news reception. With media literacy, it is expected that the public can access, sort and understand various types of information that can be used to improve the quality of life such as not easily receiving hoax news, the public can also better select which news should be spread and which cannot. Data analysis technique used in this study is a simple linear regression analysis technique to analyze the relationship of independent variables with the dependent variable with the help of the SPSS program to determine the effect of media literacy on hoax news among students of the Islamic University of Makassar. This study aims to determine the effect of media literacy on hoax news reception among Makassar Islamic University students. The results showed that there was an influence of social media literacy on hoax news reception by 0.204 , which means the percentage contribution of media literacy variable influence on hoax news reception by $20.4 \%$, while the remaining $79.6 \%$ was influenced by external variables.
\end{abstract}

Keywords: Literacy, Media, Hoax news, Students

\section{Introduction}

As social beings, humans will always desire to talk, send and receive information, exchange ideas, and share experiences. In the world of journalism, hoaxes are not new characters. Hoax is growing along with the popularity of social media such as Facebook, YouTube, Twitter, BBM, WhatsApp, Instagram, and many more that can be used for social media. This happened along with the increase in internet users in Indonesia. In 2017, eMarketer estimates that Indonesian netizens will reach 112 million people, beating Japan at number 5 with slower growth in the number of internet users. Countries of internet users in the world are respectively occupied by China, the United States, India, Brazil, and Japan [1]. Until January 2018, the number of Facebook users from Indonesia reached 130 million, the fourth largest in the world [2]

At present, the presence of a media, whether print, electronic, or internet anywhere, has a lot of influence on people's opinions and behavior. News or information is very fast circulating through social media. Those who often use social media on a daily basis will get a lot of information from social media. This allows them to be exposed more often to news with sources whose truth is unclear. Especially at this time a lot of news or writings that contain information that is not true that deliberately designed and disseminated so that people believe in incorrect information (hoaxes). For those who are not media literate, hoax news is something they think is right. The results of Jonah Berger and Katherine Milkman's study ${ }^{[3]}$ show that news that is shared virally through social 
media is news that is capable of arousing very high positive or negative emotions (high-arousal emotions). A survey conducted by Fahmi revealed $92.40 \%$ of hoaxes in Indonesia were spread through social media (Facebook, Twitter, Instagram and Path), 62.80\% hoaxes were spread through chat applications (WhatsApp, Line, Telegram) and $34.90 \%$ hoaxes were spread through the website. Whereas based on the format, hoax news that is spread in the form of writing is $62.10 \%$, while $37.50 \%$ is in the form of two-dimensional images. Research conducted by Fahmi [4]. found as many as $91.80 \%$ of the most popular hoax news in Indonesia was a socio-political issue, which specifically discussed election-related and government policies or performance, followed in number two, namely the issue of SARA (Race Racial Ethnic) and Intergroups) as much as $88.60 \%$, and health issues are number three.

The rise of these negative phenomena is responded by unrest by various groups of people, as well as our presence which is always close to the media but not accompanied by the ability to do media literacy or criticize the messages conveyed by the media well, causing the public carelessly in responding to various messages that delivered by the media. This kind of incident is not something strange when seeing various factors, including the

sophistication of the media that can interact without having to face to face so that teens can freely interact thinking carefully, media reporting that reduces facts can produce pseudo reality so that it is difficult for teenagers to distinguish between correct message and no. This illustrates how humans really need media literacy in using the internet. Media literacy can reduce hoax news reception. With media literacy it is expected that the public can access, sort and understand various types of information that can be used to improve the quality of life, for example it is not easy to receive hoax news, can select which news should be spread and which cannot.

Research on the ability of media literacy has been carried out, among others, research conducted by Muttaqin [5] with aspects approaches such as technical skills, critical understanding and communicative abilities among rural adolescents in Lamongan Regency. The results of his study indicate that the level of technical skills of rural adolescents is at the medium level, and critical understanding is at the basic level, whereas communicative abilities are at the advanced level. This research was conducted among students to determine the effect of media literacy on students' cognitive, affective, and conative abilities in receiving hoax news. The results showed that students' knowledge of hoax news was still low. When finding information with words or titles that are suggestive and even excited, they are quick to assume the news has informative value. This makes it very easy for respondents to believe hoax news.

Hoax appears in society as a reaction and lack of reference as a result of the weak media literacy. With media literacy, it is expected that the public can access, sort and understand various types of information that can be used to improve the quality of life such as not easily receiving hoax news, the public can also be more selective about what news is disseminated and what is not, what are the benefits and so on. Departing from existing thinking, it is known that basically a person's main knowledge is still a major consideration in determining whether a statement is true or false. As is the case among students who have a high level of education, they are expected to have the ability to access, choose and understand various information so that they are not easily accept hoax news. The higher education and critical power of a person, the higher the level of literacy. This research was conducted to find out whether a high level of literacy affects a students' ability to access, sort, and understand information circulating in the community.

\section{Research Method}

This research was a quantitative study that used regression analysis to measure the value of the assessment of variable indicators. The purpose of this study was to determine the effect of media literacy on hoax news reception among Makassar Islamic University (UIM) students. Respondents in this study were students from 2016 and 2017 from eight faculties totaling 3.273 students. By using the Taro Yamane formula and 5\% precision, a sample of 356 people was obtained. Data collection techniques were carried out by distributing questionnaires through Google forms which were distributed to WhatsApp groups among Makassar Islamic University students. Variable measurements were performed using a Likert scale using 1-5 scoring method. Number 1 showed that the respondent did not support the question given, while number 5 showed that the respondent supports the question given. Data were first tested using a validity test to test the accuracy of the questionnaire by using the product moment formula (Pearson's correlation). Next, a reliable test was performed to test the consistency or stability of the respondent's answers from time to time using the Cronbach Alpha formula. The data analysis technique used in this study was a simple linear regression analysis technique with the help of the SPSS program which was used to analyze the effect of media literacy on hoax news among Makassar Islamic University students. 


\section{Results and Discussion}

This research developed two variables namely media literacy and hoax news. The media literacy variable consisted of four indicators namely meaning, evaluating, analyzing, and producing. While the hoax news variable consisted of three indicators namely cognitive, affective, conative. In addition to the two scaled variables namely social media literacy $(X)$ and hoax news $(Y)$, four categorical variables were also set as control variables namely gender, generation, faculty, and activeness using social media. The determination of the control variable was done to ensure that there was no bias in this study. Bias was a presentation of material that was filled with prejudice. Bias also meant consistent errors in estimating a value.

Validity test was also carried out to find out whether the statements on the questionnaire were worthy of examination. Validity Test was carried out on 356 respondents who met predetermined criteria. Based on the validity test it could be concluded that the research instrument was feasible to use. Table 1 below was the result of calculating the validity of research instruments using SPSS 23.

Table 1. Test the validity

\begin{tabular}{cccc}
\hline \hline Indicator & $\begin{array}{c}r \text { count / correction item-total } \\
\text { correlation }\end{array}$ & $r$ table & Information \\
\hline Informatif1 & .650 & .113 & Valid \\
Kepercayaan1 & .780 & .133 & Valid \\
Sharing1 & .726 & .133 & Valid \\
Informatif 2 & .746 & .133 & Valid \\
Trust 2 & .810 & .133 & Valid \\
Sharing 2 & .800 & .133 & Valid \\
Informatif 3 & .752 & .133 & Valid \\
Trust 3 & .781 & .133 & Valid \\
Sharing 3 & .769 & .133 & Valid \\
Statement 10 & .403 & .133 & Valid \\
Statement 11 & .393 & .133 & Valid \\
Statement 12 & .470 & .133 & Valid \\
Statement 13 & .352 & .133 & Valid \\
Statement 14 & .415 & .133 & Valid \\
Statement 15 & .368 & .133 & Valid \\
Statement 16 & .349 & .133 & Valid \\
Statement 17 & .348 & .133 & Valid \\
Statement 18 & .494 & .133 & Valid \\
Statement 19 & .569 & .133 & Valid \\
Statement 20 & .451 & .133 & Valid \\
Statement 21 & .489 & .133 & Valid \\
Statement 22 & .339 & .133 & Valid \\
Statement 23 & .339 & Valid \\
\hline \hline
\end{tabular}

Source: Data processed

Then the reliability test for $X$ and $Y$ variables is conducted. Based on the results of the reliability test, it can be concluded that each item on the instrument is reliable. The reliability test results can be seen in Table 2 below.

Table 2. Reliability Tests

\begin{tabular}{cccc}
\hline \hline Variabel & Indicator & Alpha Cronbach & Information \\
\hline \multirow{3}{*}{ Media } & Meaning & .571 & Reliable enough \\
Literacy & Evaluating & .611 & Reliable \\
& Analysis & .709 & Reliable \\
& Producting & .501 & Reliable enough \\
\multirow{2}{*}{ Hoax News } & Kognitif & & \\
& Afektif & .935 & Very Reliable \\
& Konotatif & & \\
\hline \hline
\end{tabular}

Source: Data processed 
Before testing the hypothesis, the researcher conducted a t test on three nominal variables, namely gender, generation, and activity using social media, because these three variables were binary scales (only consisted of two categories). As for the faculty variable, the ANOVA test was carried out because this variable consisted of more than two categories. Based on the results of SPSS 23 software output, $t$ test results were obtained that in female sex $(M=3.95, S D=0.75)$ higher than male values $(M=3.91, S D=0.91)$ but this difference was not significant $t(191)=-0.47, p=0.63$. The SPSS output of the force category was known in the 2016 generation $(M=3.90, S D=0.88)$ which was lower than the value of the 2017 generation $(M=3.98, S D=0.71)$. However this difference was not significant because the value of $t(353)=-0.92, p=0.35$. Furthermore, SPSS output for the social media activeness category was known that the active $(M=3.95, S D=0.80)$ social media had a higher value than those who did not actively use social media $(M=3.76, S D=0.92)$ and the difference was not significant $t(16.03)=0.803, p=0.434$. In the activeness category using social media it could be concluded that there was no bias.

Table 3. T-test

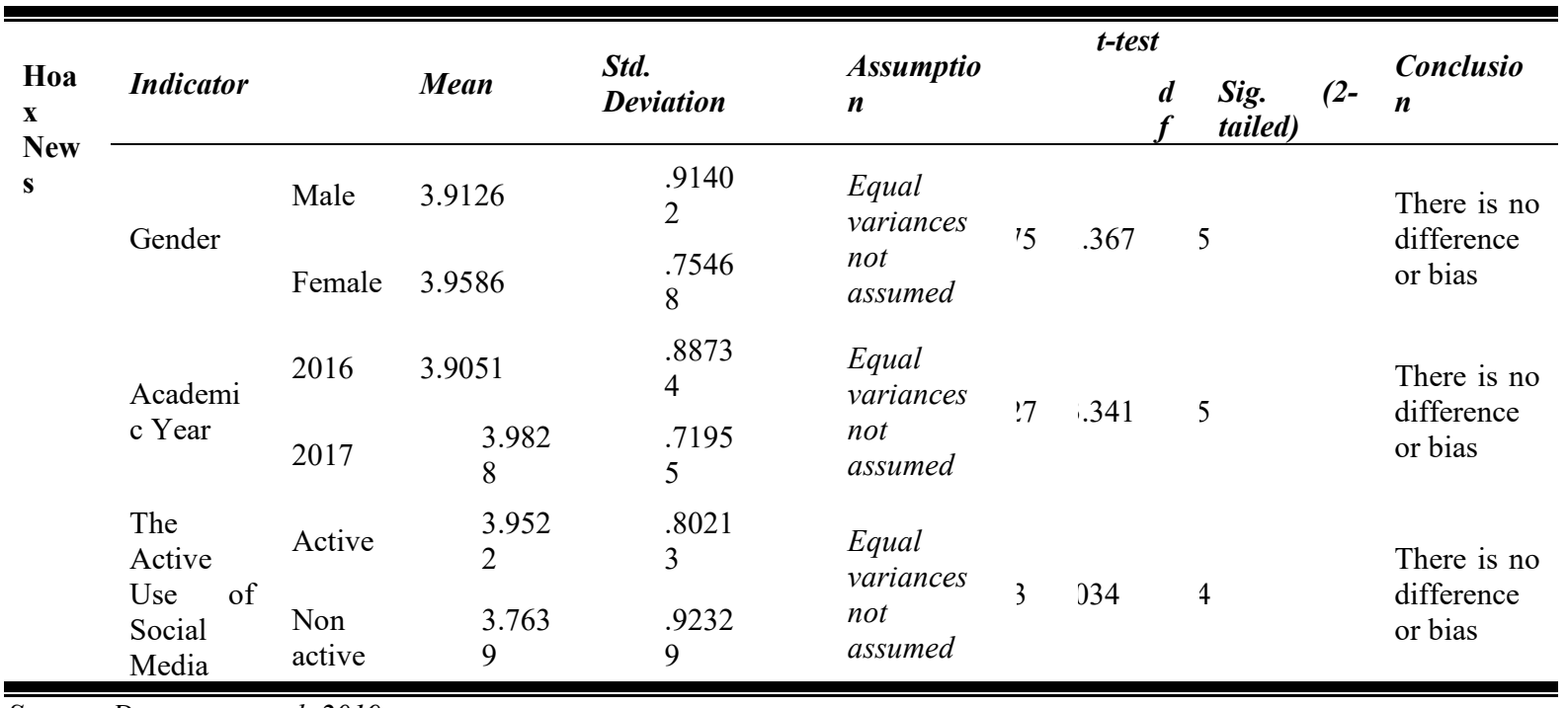

Source: Data processed, 2019

While the ANOVA test results obtained at the Faculty of Agriculture $(M=4.12, S D=0.74)$, Engineering $(M=3.83, S D=83)$, Mathmatic and Science $(M=3.93, S D=0.86)$, Social and Political Sciences $(M=4.00, S D$ $=0.72)$, Islami Religion $(M=3.91, S D=0.72)$, Literature and Humanities $(M=3.91, S D=79)$, Health Sciences $(M=3.47, S D=1.07)$, Teacher Training Education $(M=3.24, S D=0.68)$. From this value, it indicated a significant $F(7.36)=2.79 ; p=0.008$. From the ANOVA test, it could be concluded that there was a bias in the faculty category. This means that there was a significant effect on the faculty mean lower value of hoax news reception namely the health sciences faculty.

Table 4. Multiple Comparisons

\begin{tabular}{|c|c|c|c|c|c|c|c|}
\hline & \multirow[b]{2}{*}{ (i) Faculty } & \multirow{2}{*}{\multicolumn{2}{|c|}{ Mean Difference }} & \multirow[b]{2}{*}{ Std. error } & \multirow[b]{2}{*}{ Sig. } & \multicolumn{2}{|c|}{ o confidence interval } \\
\hline & & & & & & Lower Bound & Upper Bound \\
\hline \multirow[t]{4}{*}{ Bonferro } & Agriculture & Technique & .28921 & .16492 & 1.000 & -.2299 & .8082 \\
\hline & & $\begin{array}{l}\text { Mathematics } \\
\text { and natural } \\
\text { science }\end{array}$ & .18835 & .20553 & 1.000 & -.4584 & .8351 \\
\hline & & $\begin{array}{l}\text { Social } \\
\text { science and } \\
\text { political } \\
\text { science }\end{array}$ & .12524 & .14858 & 1.000 & -.3423 & .5928 \\
\hline & & Islam & .21321 & .18457 & 1.000 & -.3676 & .7940 \\
\hline
\end{tabular}




\begin{tabular}{|c|c|c|c|c|c|c|}
\hline & $\begin{array}{l}\text { Literature } \\
\text { and } \\
\text { humanities }\end{array}$ & .20693 & .21373 & 1.000 & -.4657 & .8795 \\
\hline & $\begin{array}{l}\text { Health } \\
\text { sciences }\end{array}$ & $.65043 *$ & .19164 & .021 & .0473 & 1.2535 \\
\hline & $\begin{array}{l}\text { Education } \\
\text { and teacher } \\
\text { training }\end{array}$ & -.12040 & .19164 & 1.000 & -.7235 & .4827 \\
\hline \multirow[t]{7}{*}{ Technique } & Agriculture & -.28921 & .16492 & 1.000 & -.8082 & .2299 \\
\hline & $\begin{array}{l}\text { Mathematics } \\
\text { and natural } \\
\text { science }\end{array}$ & -.10086 & .18808 & 1.000 & -.6927 & .4910 \\
\hline & $\begin{array}{l}\text { Social } \\
\text { science and } \\
\text { political } \\
\text { science }\end{array}$ & -.16397 & .12332 & 1.000 & -.5520 & .2241 \\
\hline & Islam & -.07600 & .16492 & 1.000 & -.5950 & .4430 \\
\hline & $\begin{array}{l}\text { Literature } \\
\text { and } \\
\text { humanities }\end{array}$ & -.08227 & .19701 & 1.000 & -.7022 & .5377 \\
\hline & $\begin{array}{l}\text { Health } \\
\text { sciences }\end{array}$ & .36122 & .17280 & 1.000 & -.1826 & .9050 \\
\hline & $\begin{array}{l}\text { Education } \\
\text { and teacher } \\
\text { training }\end{array}$ & -.40961 & .17280 & .512 & -.9534 & .1342 \\
\hline \multirow{7}{*}{$\begin{array}{l}\text { Mathematics } \\
\text { and natural } \\
\text { science }\end{array}$} & Agriculture & -.18835 & .20553 & 1.000 & -.8351 & .4584 \\
\hline & Technique & .10086 & .18808 & 1.000 & -.4910 & .6927 \\
\hline & $\begin{array}{l}\text { Social } \\
\text { science and } \\
\text { political } \\
\text { science }\end{array}$ & -.06311 & .17393 & 1.000 & -.6105 & .4842 \\
\hline & Islam & .02486 & .20553 & 1.000 & -.6219 & .6717 \\
\hline & $\begin{array}{l}\text { Literature } \\
\text { and } \\
\text { humanities }\end{array}$ & .01859 & .23207 & 1.000 & -.7117 & .7489 \\
\hline & $\begin{array}{l}\text { Health } \\
\text { sciences }\end{array}$ & .46208 & .21190 & .836 & -.2048 & 1.1289 \\
\hline & $\begin{array}{l}\text { Education } \\
\text { and teacher } \\
\text { training }\end{array}$ & -.30875 & .21190 & 1.000 & -.9756 & .3581 \\
\hline \multirow{4}{*}{$\begin{array}{l}\text { Social } \\
\text { science and } \\
\text { political } \\
\text { science }\end{array}$} & Agriculture & .12524 & .14858 & 1.000 & -.5928 & .3423 \\
\hline & Technique & .16397 & .12332 & 1.000 & -.2241 & .5520 \\
\hline & $\begin{array}{l}\text { Mathematics } \\
\text { and natural } \\
\text { science }\end{array}$ & .06311 & .17393 & 1.000 & -.4842 & .6105 \\
\hline & Islam & .08798 & .14858 & 1.000 & -.3796 & .5555 \\
\hline
\end{tabular}




\begin{tabular}{|c|c|c|c|c|c|c|}
\hline & $\begin{array}{l}\text { Literature } \\
\text { and } \\
\text { humanities }\end{array}$ & .08170 & .18354 & 1.000 & -.4959 & .6593 \\
\hline & $\begin{array}{l}\text { Health } \\
\text { sciences }\end{array}$ & $.52519^{*}$ & .15728 & .026 & .0302 & 1.0201 \\
\hline & $\begin{array}{l}\text { Education } \\
\text { and teacher } \\
\text { training }\end{array}$ & -.24564 & .15728 & 1.000 & -.7406 & .2493 \\
\hline \multirow[t]{7}{*}{ Islam } & Agriculture & -.21321 & .18457 & 1.000 & -.7940 & .3676 \\
\hline & Tecnique & .07600 & .16492 & 1.000 & -.4430 & .5950 \\
\hline & $\begin{array}{l}\text { Mathematics } \\
\text { and natural } \\
\text { science }\end{array}$ & .02486 & .20553 & 1.000 & -.6717 & .6219 \\
\hline & $\begin{array}{l}\text { Social } \\
\text { science and } \\
\text { political } \\
\text { science }\end{array}$ & -.08798 & .14858 & 1.000 & -.5555 & .3796 \\
\hline & $\begin{array}{l}\text { Literature } \\
\text { and } \\
\text { humanities }\end{array}$ & -.00628 & .21373 & 1.000 & -.6789 & .6663 \\
\hline & $\begin{array}{l}\text { Health } \\
\text { sciences }\end{array}$ & .43722 & .19164 & .647 & -.1659 & 1.0403 \\
\hline & $\begin{array}{l}\text { Education } \\
\text { and teacher } \\
\text { training }\end{array}$ & -.33361 & .19164 & 1.000 & -.9367 & .2659 \\
\hline \multirow{7}{*}{$\begin{array}{l}\text { Literature } \\
\text { and } \\
\text { humanities }\end{array}$} & Agriculture & -.20693 & .21373 & 1.000 & -.6795 & .4657 \\
\hline & Technique & .08227 & .19701 & 1.000 & -.5377 & .7022 \\
\hline & $\begin{array}{l}\text { Mathematics } \\
\text { and natural } \\
\text { science }\end{array}$ & -.01859 & .23207 & 1.000 & -.7489 & .7117 \\
\hline & $\begin{array}{l}\text { Social } \\
\text { science and } \\
\text { political } \\
\text { science }\end{array}$ & -.08170 & .18354 & 1.000 & -.6593 & .4959 \\
\hline & Islam & .00628 & .21373 & 1.000 & -.6663 & .6789 \\
\hline & $\begin{array}{l}\text { Health } \\
\text { sciences }\end{array}$ & .44350 & .21987 & 1.000 & -.2484 & 1.1354 \\
\hline & $\begin{array}{l}\text { Education } \\
\text { and teacher } \\
\text { training }\end{array}$ & -.32734 & .21987 & 1.000 & -1.0192 & .3646 \\
\hline \multirow{4}{*}{$\begin{array}{l}\text { Health } \\
\text { sciences }\end{array}$} & Agriculture & $-.65043 *$ & .19164 & .021 & -1.2535 & -.0473 \\
\hline & Technique & -.36122 & .17280 & 1.000 & -.9050 & .1826 \\
\hline & $\begin{array}{l}\text { Mathematics } \\
\text { and natural } \\
\text { science }\end{array}$ & -.46208 & .21190 & .836 & -1.1289 & .2048 \\
\hline & $\begin{array}{l}\text { Social } \\
\text { science and }\end{array}$ & $-.52519^{*}$ & .15728 & .026 & -1.0201 & -.0302 \\
\hline
\end{tabular}




\begin{tabular}{|c|c|c|c|c|c|c|}
\hline & \multicolumn{6}{|l|}{$\begin{array}{l}\text { political } \\
\text { science }\end{array}$} \\
\hline & Islam & -.43722 & .19164 & .647 & -1.0403 & .1659 \\
\hline & $\begin{array}{l}\text { Literature } \\
\text { and } \\
\text { humanities }\end{array}$ & -.44350 & .21987 & 1.000 & -1.1354 & .2484 \\
\hline & $\begin{array}{l}\text { Education } \\
\text { and teacher } \\
\text { training }\end{array}$ & $-.77083^{*}$ & .19847 & .003 & -1.3954 & -.1463 \\
\hline \multirow{7}{*}{$\begin{array}{l}\text { Education } \\
\text { and teacher } \\
\text { training }\end{array}$} & Agriculture & .12040 & .19164 & 1.000 & -.4827 & .7235 \\
\hline & Technique & .40961 & .17280 & .512 & -.1342 & .9534 \\
\hline & $\begin{array}{l}\text { Mathematics } \\
\text { and natural } \\
\text { science }\end{array}$ & .30875 & .21190 & 1.000 & -.3581 & .9756 \\
\hline & $\begin{array}{l}\text { Social } \\
\text { science and } \\
\text { political } \\
\text { science }\end{array}$ & .24564 & .15728 & 1.000 & -.2493 & .7406 \\
\hline & Islam & .33361 & .19164 & 1.000 & -.2659 & .9367 \\
\hline & $\begin{array}{l}\text { Literature } \\
\text { and } \\
\text { humanities }\end{array}$ & .32734 & .21987 & 1.000 & -.3646 & 1.0192 \\
\hline & $\begin{array}{l}\text { Health } \\
\text { sciences }\end{array}$ & $.77083^{*}$ & .19847 & .003 & .1463 & 1.3954 \\
\hline
\end{tabular}

Source: Data processed

The Post Hoc Test was a continuation of the ANOVA test. This test was done to find out which groups were different and which were not different. Or in this case it could be said which faculty group had a significant influence on hoax news reception. Based on the above data it was seen that there were significant differences in the mean of the faculties of agriculture, social political science, health sciences, and teacher science. Of the four faculties, hoax news reception on health sciences were significantly lower compared to agriculture, social and political science, and teacher training. So the results of this study needed to be responded with more caution because it did not apply to all students of the Makassar Islamic University.

The SPSS test results showed that there was no significant difference in receiving hoax news based on gender, generation, and activeness using social media, because the probability value was greater than the value of 0.05 . But there was a significant difference in reception of hoax news based on faculty, because the probability value was smaller than 0.05 .

Table 5. Differences in categorical variables

\begin{tabular}{ccccc}
\hline & \multicolumn{3}{c}{ Table 5. Differences in categorical variables } \\
\hline \hline \multirow{2}{*}{ Gender } & $\begin{array}{l}\text { Academic } \\
\text { year }\end{array}$ & Faculty & $\begin{array}{l}\text { The Active Use of Social } \\
\text { Media }\end{array}$ \\
\hline $\begin{array}{l}\text { Berita } \\
\text { Hoax }\end{array}$ & .635 & .355 & .008 & .434 \\
\hline \hline
\end{tabular}

Furthermore, hypothesis testing was done through regression analysis at SPSS to determine the effect of media literacy variables on hoax news. Based on the results of a simple regression analysis, in the Summary Model output, Adjusted $R$ Square had a value of 0.204 , which meant the percentage contribution of the influence of media literacy variables to hoax news reception was $20.4 \%$, while the remaining $79.6 \%$ was influenced by external variables. Based on the Coefficients output, it was concluded that the relationship between media literacy and hoax news reception were very significant or highly correlated. In the ANOVA Output, the Sig. 0,000 and level $5 \%$, which meant the value of Sig. $=0,000<0.05$. So that it could be concluded that $H o$ was rejected and $H a$ was accepted, it was meant that there was an influence of social media literacy on hoax news reception. 
Table 6. Model Summary

\begin{tabular}{llllll}
\hline \hline Model & $R$ & $R$ Square & $\begin{array}{l}\text { Adjusted } \\
\text { Square }\end{array}$ & $\begin{array}{l}\text { Std Error of the } \\
\text { Estimate }\end{array}$ \\
\hline 1 & $.461^{\mathrm{a}}$ & .213 & .204 & .72008 \\
\hline \hline
\end{tabular}

a. predictors (Constant)

Table 7. ANOVA

\begin{tabular}{llrrrrl}
\hline \hline \multirow{3}{*}{ Model } & \multicolumn{5}{c}{ Sum of } & \multicolumn{1}{c}{ Mean } \\
Squares & Df & Square & $F$ & Sig \\
\hline \multirow{2}{*}{1} & & 51.443 & 4 & 12.861 & 24.803 & $.000^{\mathrm{b}}$ \\
\cline { 2 - 8 } & Regression & 190.297 & 367 & .519 & & \\
\cline { 2 - 7 } & Residual & 241.741 & 371 & & & \\
\cline { 2 - 7 } & Total & & & & & \\
\hline \hline
\end{tabular}

a.Dependent Variable

b.Predictors (Constant)

Table 8. Coefficients ${ }^{\text {a }}$

\begin{tabular}{|c|c|c|c|c|c|c|}
\hline \multirow[b]{2}{*}{ Model } & & \multicolumn{2}{|c|}{$\begin{array}{c}\text { Unstandardized } \\
\text { Coefficients }\end{array}$} & \multirow{2}{*}{$\begin{array}{c}\text { Standardized } \\
\text { Coefficients } \\
\text { Beta }\end{array}$} & \multirow[b]{2}{*}{$t$} & \multirow[b]{2}{*}{ Sig } \\
\hline & & $B$ & Std. Error & & & \\
\hline \multirow[t]{5}{*}{1} & $($ Constant $)$ & 1.503 & .252 & & 5.970 & .000 \\
\hline & Meaning & -.145 & .075 & -.138 & -1.937 & .053 \\
\hline & Evaluating & .552 & .097 & .404 & 5.694 & .000 \\
\hline & Analysis & .213 & .079 & .190 & 2.710 & .007 \\
\hline & Production & .002 & .041 & .003 & .050 & .960 \\
\hline
\end{tabular}

1) In the summary model output, Adjusted $R$ Square had a value of 0.204 which meant the percentage contribution of the influence of media literacy variables to the reception of hoax news was $20.4 \%$. While the remaining $79.6 \%$ was influenced by external variables.

2) In the model summary output, the Standard Error of the Estimate had a value of .720. Standard Error of the Estimate was a measure of prediction error. In this case, an error could occur in predicting a hoax news reception value of .720 .

3) Based on the output of coefficients a it was concluded that the relationship between media literacy and hoax news reception was significant or related.

4) Testing Criteria:

- If the level of Sig value > 0.05, then Ho was accepted.

- If the value of Sig. $\leq 0.05$, then $H o$ was rejected.

5) In table 7 the ANOVA outputs were of Sig. 0,000 and 5\% level. From the table above it is known that the value of Sig. $=0,000<0.05$. So it could be concluded that $H o$ was rejected and $H a$ was accepted. This meant that there was an influence of social media literacy on hoax news reception. As stated in the previous paragraph that social media literacy had an effect of $20.4 \%$ on hoax news reception, while the remaining $79.6 \%$ was influenced by other variables outside media literacy.

\section{Conclusion}

Based on the results of a simple regression analysis it could be concluded that there was an influence between social media literacy and hoax news. The level of media literacy understanding of Makassar Islamic University students was still very low and their literacy abilities were not optimal yet in responding to hoax news on social media. In the ability to analyze, Islamic University students as social media users were not familiar yet with scientific traditions such as questioning every news received and comparing news from social media with other news sources. In the ability to produce, only a few respondents could edit their own news that was found to be spread on social media, while others spread the news exactly the same as those obtained from others. The level of knowledge of Makassar Islamic University students on hoax news was also still low. When found information with words or titles that were suggestive and even excited, they were quick to assume the news had informative value. This made it very easy for respondents to believe hoax news. 


\section{References}

[1] Kominfo.: Pengguna Internet Indonesia Nomor Enam Dunia. Nov. 24. https://kominfo.go.id (2014)

[2] Kompas.: Indonesia Pengguna Facebook Terbanyak ke-4 di Dunia. https://tekno.kompas.com (2018)

[3] Struhar, C.: The Facebook Effect on the News. The Atlantic. www.theatlantic.com/business (2016)

[4] Fahmi,Ismail.: Perilaku Masyarakat Indonesia terhadap Hoax Media dan Budaya Baca. www.slideshare.net (2017)

[5] Muttaqin, Misbah Zaenal.: Kemampuan Literasi Media (Media Literacy) di Kalangan Remaja Rural di Kabupaten Lamongan. http://lib.unair.ac.id (2019)

[6] Gumgum, G., Justito, A., \& Nunik, M. Literasi Media.: Cerdas Menggunakan Media Sosial Dalam Menanggulangi Berita Palsu (Hoax) Oleh Siswa Sma. Pengabdian Kepada Masyarakat, Vol.1.pp.35-40. https://doi.org/1410 - 5675 (2017)

[7] Alyusi, Shiefti Dyah.: Media Sosial: Interaksi, Identitas dan Modal Sosial (Jakarta: Prenadamedia Group) (2016)

[8] Cangara, Hafied.: Pengantar Ilmu Komunikasi (Jakarta: Raja Grafindo Persada Dirgayuza) (1998)

[9] Jalaluddin, Rakhmat.: Psikologi Komunikasi (Bandung: Rosda Karya) (2005)

[10] Mulyana, Deddy.: Ilmu Komunikasi Suatu Pengantar (Bandung: Remaja Rosdakarya) (2008)

[11] Raharjo, Turnomo.: Literasi Media dan Kearifan Lokal: Konsep dan Aplikasi (Salatiga: UKSW dan ASPIKOM) (2012)

[12] Rakhmat, Jalaluddin.: Metode Penelitian Komunikasi Dilengkapi dengan Contoh Analistik Statistik (Bandung: PT Remaja Rosdakarya) (2004)

[13] Rochimah, Nur dan Junaedi, Fajar.: Tips Memilih Program Televisi, Internet, Dan Media Massa Yang Tepat Bagi Anak (Yogyakarta: Mata Padi Presindo,Yogyakarta) (2013)

[14] T. H.: Gerakan Literasi Media Melindungi Anak-Anak dari Gempuran Pengaruh Media Gerakan Literasi Media Indonesia (Yogyakarta: Rumah Sinema) (2011)

[15] Siregar, Syofian.: Metode Penelitian Kuantitatif: Dilengkapi dengan Perbandingan Perhitungan Manual \& SPSS (Jakarta: Kencana Prenada Media Group) (2013)

[16] Sugiyono.: Metode Penelitian Kuantitatif, Kualitatif, dan Kombinasi (Mixed Methods) (Bandung: CV. Alfabeta) (2013)

[17] Sunarto. : Literasi Media dan Kearifan Lokal: Konsep dan Aplikasi (Salatiga: UKSW dan ASPIKOM) (2012)

[18] Tamburaka, Apriadi.: Literasi Media: Cerdas Bermedia Khalayak Media Massa (Jakarta: Rajawali Pers) (2013)

[19] Adelina, Sonya.: Pemahaman Literasi Media Baru Terhadap Penyebaran Berita Hoax Di Media Sosial Instagram Pada Kalangan Mahasiswa Universitas Sumatera Utara. Skripsi. Medan: Program Strata 1 (S1). Universitas Sumatera Utara (2018)

[20] Aniroh, Nur Azizah Dewi. Sikap Mahasiswa Terhadap Pesan Kebencian Dan Berita Palsu Di Facebook Terkait Kasus Basuki Tjahaya Purnama Yang Disebarkan Oleh Saracen (Studi Deskriptif Kuantitatif Pada Mahasiswa/I Strata 1 Fakultas Ilmu Sosial Dan Ilmu Politik Universitas Lampung Angkatan 2015). Skripsi. Bandar Lampung: Program Strata 1 (S1). Universitas Lampung (2018)

[21] Baroroh, J.K.S.: Literasi Media Digital Mahasiswa Universitas Muhammadiyah Bengkulu. Jurnal. Bengkulu Universitas Muhammadiyah Bengkulu (2016)

[22] Mutmainah, Anna.: Tingkat Literasi Media Mahasiswa Komunikasi Surakarta Tentang Pemberitaan Kopi Beracun Sianida Di Tv One (Studi Kasus Mahasiswa Komunikasi UNS, UMS, Dan IAIN Surakarta). Skripsi Surakarta: Program Strata 1 (S1) Institut Agama Islam Negeri Surakarta (2017)

[23] Oktavianti, Roswita.: Penggunaan Media Sosial Sesuai Nilai Luhur Budaya di Kalangan Siswa SMA. (2017)

[24] Susilawati.: Tanggapan Mahasiswa Ilmu Komunikasi Universitas Hasanuddin Terhadap Berita Palsu (Hoax) Pada Portal Berita (2017) 